
\title{
Developing Integrated Curriculum with Environmental Education at Vocational High School
}

\author{
Warju$^{1}$, Sudirman Rizki Ariyanto², Lutfi Muzaki² \\ Department of Mechanical Engineering, Faculty of Engineering ${ }^{1}$ \\ Technical and Vocational Education, Graduate School ${ }^{2}$ \\ Universitas Negeri Surabaya \\ warju@unesa.ac.id
}

\begin{abstract}
The issue of the environment is an important topic that needs serious attention. Global warming and environmental pollution is one proof that human activity has a direct impact on environmental preservation. The purpose of this study was to determine how the ideal concept of curriculum development of automotive engineering study program integrated with the environmental education (EE) at vocational high school. The research method was used in this research is a literature review. The data collected by conducting a literature review of scientific books, research reports, scientific articles, theses and dissertations, regulations, laws, and other sources related to the matter being investigated. The results showed that, conceptually, the model of curriculum development of automotive engineering study program integrated with EE at vocational high school is an ideal model if implemented by the green school (called here after, 'adiwiyata') program. The model has a solid foundation because it is developed through the several steps that must be done sequentially starting from the first step up to the last stage. First, the schools should conduct a curriculum study. Second, the schools conduct a SWOT analysis to sort out the factors that affect the four categories of the adiwiyata program. It is environmental policy, implementation of environmentally-based curriculum, participatory-based ecological activities, and management of environmentallyfriendly automotive technology. Third, the schools develop an action plan to determine the set of policies and targets to be achieved. Fourth, the school develops curriculum based on four components of the adiwiyata program. Fifth, the expected results are graduated who have the expertise competence and have a good behavior towards the environment by the concept of sustainable development.
\end{abstract}

Keywords-curriculum, green school (adiwiyata) program, environmental education

\section{INTRODUCTION}

The issue of the environment is an important topic that needs serious attention. Global warming and environmental pollution is one proof that human activity has a direct impact on environmental degradation. Therefore, to maintain and preserve ecological conditions, all human actions must reflect a caring attitude towards the environment by the concept of sustainable development.

Sustainable development is a global paradigm used by all members of the United Nations. The concept of sustainable development is described as a development to meet the needs of the present generation without compromising the ability of future generations to meet their own needs [1]. Therefore, EE becomes an urgent requirement. EE evolves through long stages and historical processes. The initial discussion on the issue of EE began on 13 - 22 October 1975 in an international workshop on environmental education in Belgrade, Yugoslavia [2].

The conference produced some of the intergovernmental statement concerning environmental education, known as "The Belgrade Charter - A Global Framework for Environmental Education" [2], Subsequently, on 14 to 26 October 1997 held an intergovernmental conference on EE. The meeting was organized by UNESCO and UNEP. The meeting resulted in the Tbilisi Declaration adopted by the acclamation. The Declaration notes a vital agreement related to the role, purpose, and characteristics of EE [3].

In Indonesia, for a healthy environment and well into the rights of all citizens. This has been regulated in the 1945 Constitution of the Republic of Indonesia [4], To achieve these objectives the Ministry of Environment and Forestry developed EE programs, both at the level of primary and secondary education through the green school (adiwiyata) program [5].

Adiwiyata program implementation is a mandate of Law Number 32 of 2009 on the Protection and Environmental Management, while the follow-up contained in the Regulation of the Minister of Environment of the Republic of Indonesia No. 05 of 2013 on the implementation of the Adiwiyata Program Guidelines [6], [7], The primary purpose of the Adiwiyata program is to create a right school conditions for teaching and learning. It is also to sensitize the school community that we take responsibility for efforts to save the environment and sustainable program

The implementation of the adiwiyata program did on the level of elementary school, junior high school, high school, and vocational high school. However, the application still there are several factors that make the discrepancy between the expected goals with reality [8], These factors substantially caused by several aspects. First, the planning includes: yet formulated an integrated curriculum-based environmental education program with particular expertise in the automotive engineering school. Second, the lack of 
facilities and infrastructures supporting ecological programs based on automotive engineering study programs such as technology reducing exhaust emissions, opacity, noise level, and oil waste processing of laboratory results. Third, the concept of curriculum development has not been found, an especially ideal model for integrating curriculum with $\mathrm{EE}$ at vocational high school. Fourth, EE tends to be used only by administrative level. It has not been based on efforts to change the behavior of school people to care for the environment. Therefore, the concept of curriculum development of vocational high schools in automotive engineering study program integrated with EE becomes very important.

By the main problem and problem-causing factors described in the background of the problem, then the formulation of the problem to be presented in this research is how the ideal concept of curriculum development in automotive engineering study program integrated with $\mathrm{EE}$ at vocational high schools?

\section{LITERATURE REVIEW}

\section{A. Curriculum}

The curriculum was initially a term used in the field of sports. The word curriculum comes from Greek, i.e., from Curir (runner) and Currere (the place of race). At that time, the curriculum is defined as the distance that must be taken by athlete runners. Then the term began to be used in education with the meaning of some subjects that must be completed by a student from the beginning to the end of the learning program [9].

Science is always changing and evolving to follow the progress of time, as well as in the field of education. Changes in education will directly affect the view of the curriculum. The curriculum that was initially viewed merely as some subjects later changed to include all school documents, newspaper articles and all topics offered [10].

Vocational education is a system that cannot be separated from the overall education system. However, vocational education curriculum has different characteristics and orientation of the educational system. The difference lies not only in the definition, organizational structure, and educational purposes only. However, it is seen in other aspects that have relevance to curriculum planning aspects [11].

\section{B. Green Schools}

Green Schools is an international educational program offered to school to become an essential part of efforts to control environmental issues. A school is classified as a green school is not based on the physical appearance of the school are green and leafy, but realized through educational programs and activities that lead to the behaviors of caring for the environment [12].

In the physical appearance of green schools should have an ecological order. The environmental law serves as a means for learning in schools in fostering attitudes and behaviors friendly to the environment for the entire school community. Green school became one of the EE efforts through academic pathways. The purpose of the school is to provide an understanding of the green-related real meaning of green schools, which "behaves to create a quality of school environment, conducive, ecological, real sustainable and sustainable manner by the values and cultural wisdom" [13].

\section{Guidelines for Green Schools in the United States \\ 1) U.S. Green Building Council (USGBC-LEED) for School}

The United States Green Building Council (USGBC) is an institution founded by Rick Fedrizzi, David Gottfried and Mike Italiano, which was established in 1993. Initially, this institute founded with the mission of promoting sustainability in the building and construction industry. However, in April there was a meeting involving representatives from about 60 companies and several nonprofit organizations at the American Institute of Architects' that addresses green building assessment scheme in order to have international standards of environmentally sound [14], To meet these objectives, in March 2000, USBGC establish leadership energy and environment design (LEED) certification as a green building assessment scheme. LEED project devoted to commercial, institutional and residential [15].

Then in 2007, USBGC launched a national Green Schools Joint campaign with several partners in the Clinton Global Initiative. Also, USGBC also launched a LEED scoring system specifically used for schools. LEED for School provides a standard or criteria to be met by the principal to create buildings and school conditions are conducive, comfortable for the learning process, and healthier. After that, the USGBC established the Center for Green Schools in 2010. The purpose of the establishment of Center for Green Schools is to expand the green building movement to cover essential topics and issues in the school and the school community (teachers, students, staff, and parents) [16].

The scoring scheme used by LEED for school in assessing a building adjusts fourteen (14) main criteria, which are (1) indoor air quality; (2) thermal comfort; (3) acoustic; (4) day lighting; (5) solar panels; (6) green roof; (7) water efficiency; (8) energy efficiency; (9) energy efficient lighting; (10) mold prevention; (11) joint use of facilities; (12) recycling; (13) low-emitting materials; and (14) the alternative transport option [17].

\section{2) Collaborative for High-Performance Schools (CHPS)}

The CHPS organization worked from 1999 as California's premier utility collaboration to address energy efficiency in schools. This program was developed specifically to reduce energy consumption in educational facilities in California as a means to reduce operating costs $[18,19]$. For more than 15 years, CHPS has run the mission with the hope of K-12 educational facilities can be designed well. Thus, it can improve student's performance; positively affect the health of students, teachers, or staff; make education more fun and rewarding; and can promote proper environmental management [20].

There are ten (10) criteria used as guidelines by CHPS in building green schools, which are: (1) health and indoor air quality (IAQ); (2) thermal comfort; (3) acoustic; (4) day lighting; (5) water efficiency; (6) energy efficiency; (7) lowemitting alternative materials; (8) material efficient; (9) site selection; and (10) chemical pollutant source control [21]. 


\section{3) U.S. Environmental Protection Agency (U.S. EPA)}

The United States Environmental Protection Agency (U.S. EPA) is a United States federal government agency responsible for protecting the health and the environment based on laws passed by the Congress. The EPA began operations on December 2, 1970, proclaimed by President Richard Nixon. The EPA is not a cabinet institution, but its administrators are assigned cabinet ratings [22].

In building a green school, EPA has 12 criteria were used as a reference, such as (1) health and indoor air quality (IAQ); (2) thermal comfort; (3) acoustic; (4) day lighting; (5) water efficiency; (6) energy efficiency; (7) energy efficient lighting; (8) material efficient; (9) easy to mantain and operate; (10) save and secure; (11) commissioned; and (12) site selection [23].

\section{Guidelines for Green Schools in Indonesia}

In Indonesia, the green school's program known as 'adiwiyata' program derived from Sanskrit that is, "Adi" and "Wiyata." "Adi" has great significance, noble, ideal or perfect. Meanwhile, the word "Wiyata" has the meaning of a place that is used as a reference someone in getting knowledge, norms, and ethics in social life. If the two words are combined then, meaning in terms 'adiwiyata' is an ideal and enjoyable place to help a person in gaining knowledge, norms, and ethics that can be used as a fundamental human and prosperous life toward achieving the goal of sustainable development [13].

In developing green schools (adiwiyata) program in Indonesia, there is four components that must be considered by the school, namely: (1) environmental policy; (2) implementation of the environmentally-based curriculum; (3) participatory-based ecological activities (4) management of environmetally-friendly infrastructure and facilities [24]. For more details can be seen in Figure 1.

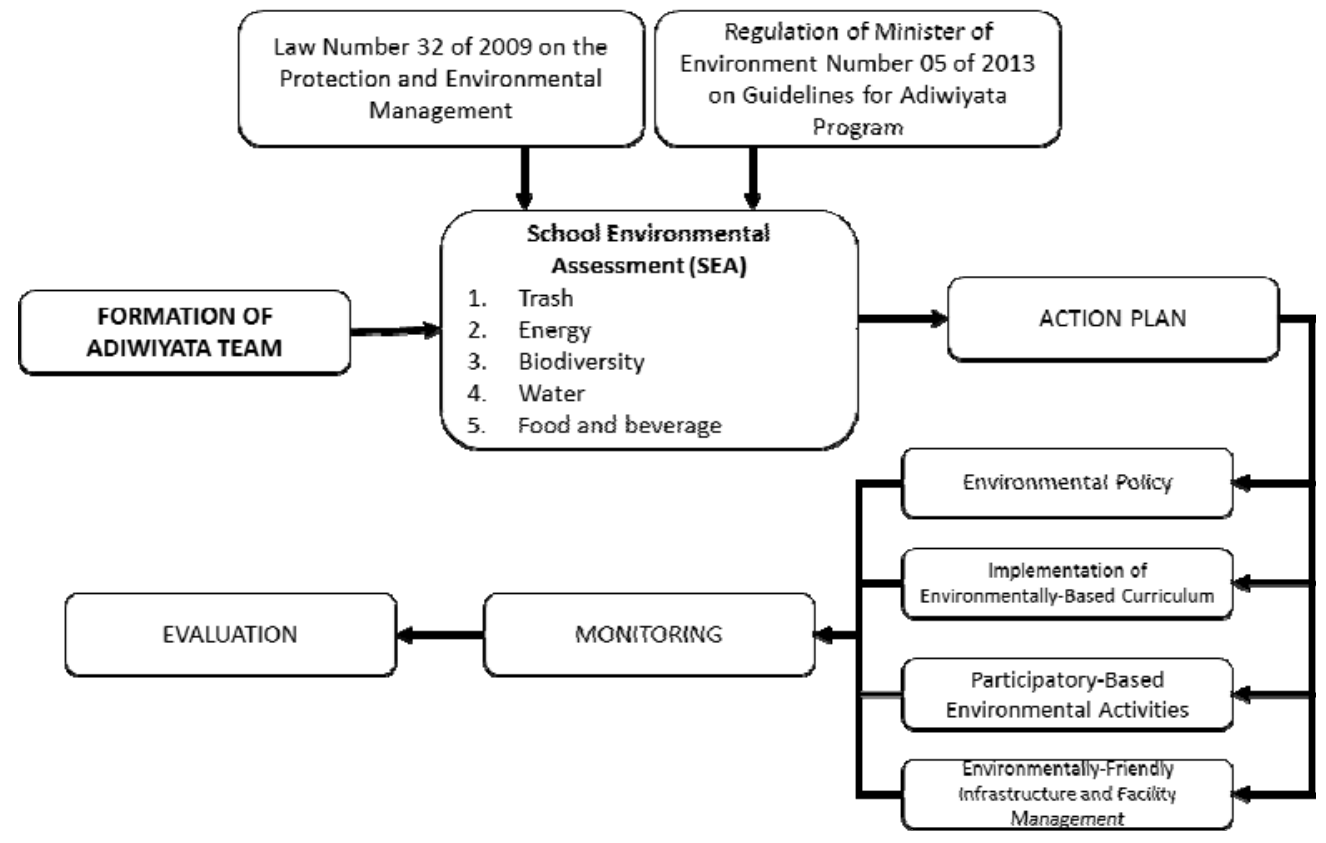

Fig. 1. The Existing Model of Green School (Adiwiyata) Program in Indonesia

The four components above, have a mutually sustainable relationship. The integration of EE begins with the fulfillment of environmentally-friendly infrastructure and facilities at schools. Generally, environmentally-friendly support and facilities provided by schools such as organic and inorganic waste bins, waste chopsticks, composters, biopore, etc. Infrastructure and facilities that have been fulfilled (provided) will make it easier for schools in designing policies, curriculum integration, and activities that support adiwiyata program.

Green schools either in Indonesia or other countries using the same concept of the program and award scheme. The idea of the green school's program development is generally carried out by the adoption of manuals that have been provided by each country. While the green school award can only be obtained when these schools meet all the essential elements of the green school's program criteria [12].

\section{RESEARCH METHOD}

This research is a literature review. Research literature review that activity to gather information relevant to the topic or issue that made the object of study [25]. Data collected by conducting a literature review of scientific books, research reports, scientific articles, theses and dissertations, regulations, laws, and other sources related to the matter being investigated.

There are three reasons why the study was conducted. First, the problem of this research is ideal if done through literature review because the concept of green schools used as a comparison comes from the United States, so it does not allow the existence of field studies. Second, the literature review is required as preliminary studies to understand whether the 
issues addressed an important point to be solved. Third, the library data used remains reliable to answer the problem under investigation.

Data analysis techniques in research and development using the qualitative descriptive method. Qualitative descriptive is the data described in a sentence that is easily understood as an effort to get answers to the problems statement [26]. This is done to provide an idea of the ideal concept in developing of automotive engineering study program curriculum that is integrated with $\mathrm{EE}$ at vocational high school.

\section{RESUlt AND DiscUSSION}

Based on the analysis and synthesis, a grand design of curriculum combined with $\mathrm{EE}$ in an automotive engineering study program at the vocational high school is found as follows.

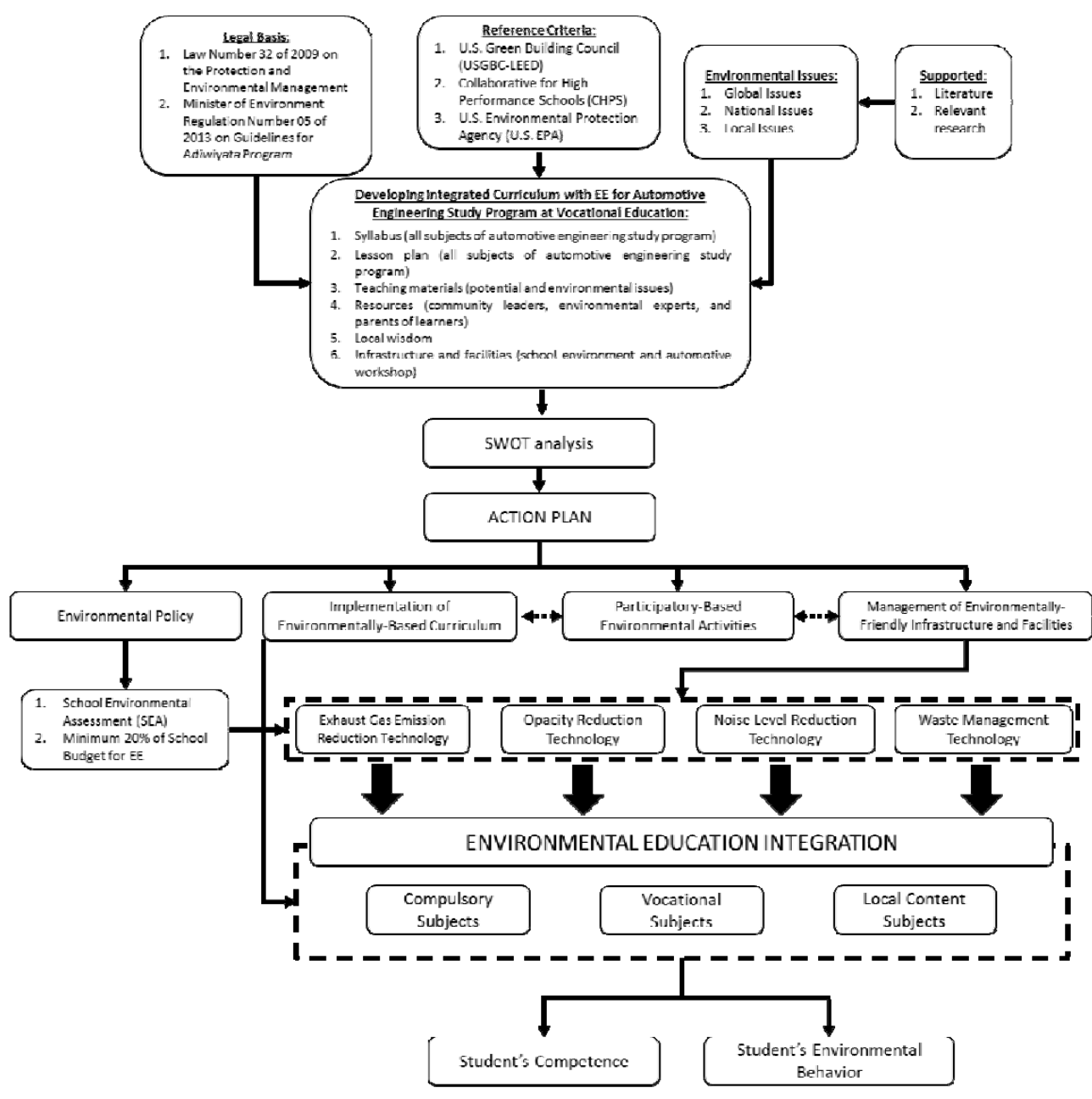

Fig. 2. The New Models of Curriculum Development of Automotive Engineering Study Program Integrated with EE at Vocational High School

The above model is analyzed and synthesized based on the ideal concept of adiwiyata program implementation in vocational high schools, especially in the automotive engineering study program. The perfect idea of the adiwiyata program in automotive engineering study program consists of several steps that must be performed in sequence starting from the first step up to the last stage.

First, before starting the curriculum development, curriculum review needs to be done. Curriculum studies conducted to find a picture of the current school curriculum. The curriculum being studied include: (1) the syllabus; (2) lesson plan; (3) teaching materials; (4) speakers; (5) local wisdom; and (6) infrastructure and facilities. This is by Gleissner's statement (2013), which states that the development of curriculum, teaching materials, cooperation, facilities, and infrastructure are a few required steps in developing a green school [27].

The curriculum review is based on the several indicators, namely the legal basis, the reference criteria, and environmental issues. The legal basis is adjusted to Law Number 32 of 2009 on Environmental Protection and Management and Minister of Environment Regulation Number 
05 of 2013 on Guidelines for Adiwiyata Program [6], [7]. Furthermore, analyzing reference criteria by adopting the concept of green school applicable in some developed countries such as the United States.

In the United States, there are several institutions tasked with monitoring and controling of green schools. Some of these institutions are U.S. Green Building Council-Leadership Energy and Environment Design (USGBC-LEED), Collaborative for High Performance Schools (CHPS), dan U.S. Environmental Protection Agency (U.S. EPA) [28], [21], [23]. Then, the teaching materials used by teachers should be based on potential and environmental issues which are supported by much of the literature and relevant research. Also, parents and communities also need to be actively involved as a supporter of the adiwiyata program [5].

Second, do a SWOT analysis. The SWOT analysis was undertaken to evaluate the stengths, weaknesses, opportunities, and threats to the curriculum development of an automotive engineering study program integrated with EE at vocational high schools. According to Thompson et al. (2016), the SWOT analysis is a simple measuring capable tool for measuring external strengths, weaknesses, opportunities, and threats [29]. SWOT analysis is applied by analyzing and sorting out the factors that affect the four categories of the adiwiyata program.

Stengths (S), (1) the curriculum of automotive engineering study program integrated with $\mathrm{EE}$ at vocational high schools is the result of adoption in prevailing green school concept in the United States. (2) The curriculum is highly relevant to the vision, mission, goals, and objectives of the adiwiyata program: to realize the school community are responsible for the environment to support sustainable development [13]. Weaknesses (W), 1) required environmentally-friendly infrastructure and facilities adequate; (2) the ability of teachers to integrate EE into vocational subjects is low.; (3) the school budget for EE under $20 \%$ of the total school budget.

Opportunities $(O),(1)$ increase the efficiency of school fund use through saving of resources and energy; (2) creating a more conducive learning conditions; (3) fostering environmental values for the citizens of the school and surrounding communities; (4) be one solution in controlling environmental pollution, damage and preserve function [13]. Threats (T), (1) considerable curriculum demands can lead to student delays in completing their studies; (2) the lack of adequate facilities and infrastructure that will cause maximal learning process with a charge of EE; (3) if the commitments are built in developing green school is less intense, then the meaning adiwiyata obtained only limited to physical appearance alone.

Third, the action plan. The action plan is the result of the development of curriculum studies that have been done before. The action plan contains a series of plans and targets to be achieved. The determination of the action plan to adjust the environmental issues which have been taking into account the priorities of needs, capabilities, cost, and time allocation. Some of them are controlling exhaust gas emissions, and opacity (smoke) was included in the health and indoor air quality (IAQ), and chemical pollutant source control. Control of noise level included in the health and indoor air quality (IAQ), acoustic, and chemical pollutant source control. Noise management, including chemical pollutant source control) [28], [21], [23]. In facing these four issues, schools must have the resources and infrastructure that support the settlement of these problems. The school also had to prepare an instrument that can be used to measure program performance.

Fourth, develop curriculum based on the four components of the adiwiyata program. The four elements are (1) environmental policy; (2) implementation of the environmentally-based curriculum; (3) participatory-based ecological activities; and (4) management of environmentallyfriendly infrastructure and facilities [13], [24].

Environmental policy is the first component to be done. The activities include conducting a school ecological assessment (SEA) and making budgeting policy of minimum $20 \%$ of the total school budget for EE. SEA is used to calculate the potential of total emissions $\left(\mathrm{CO}, \mathrm{HC}, \mathrm{NOx}, \mathrm{SOx}, \mathrm{PM}_{10}\right.$, and $\mathrm{CO}_{2}$ ), noise level, vibration, and waste resulting from school. Moreover, automotive technology can be used to reduce exhaust gas emissions, opacity (smoke emission), noise level, vibration, and waste. Once, the school knows what needs to be met; then the results are used to construct SEA and using 20\% of the school budget for EE.

The next activity is the management of environmentallyfriendly infrastructure and facilities. Based on the SEA and school budget allocation, schools are required to make environmental protection and management supporting infrastructure and facilities according to the needs of automotive engineering study program. Some of them carried out by developing environmentally-friendly automotive technologies such as (1) exhaust gas emissions reduction technology, such as by using catalytic converter technology; (2) opacity (smoke emission) reduction technology, such as by using diesel particulate filter (DPF) technology; (3) noise level reduction technology, such as by using off-set tube type muffler technology; and (4) technology can be used to treat oil waste, such as oil filter cleaner. However, according to Warju et al. (2017), especially environmentally-friendly automotive technology for vocational high school development such as alternative energy manufacturing technology, emission control technology, noise level reduction technology, vibration control technology, and waste management technology can not maximize yet [24].

Development of environmentally-friendly automotive technology should involve students, teachers, administrative staff, individual service officer, and school committees. It is participatory-based environmental activities. It is intended that not only teachers that are instrumental in the development of infrastructure and facilities but also students are actively involved. Thus, in addition to the students gain knowledge of existing technology in the world of the automotive engineering industry, they also can make and knows the importance of technology to support the protection and management of the environment. Moreover, in the development of school facilities and infrastructure is required to carry out the cooperation with various agencies such as the department of the environment and the local health department to give each other the knowledge related to the EE [27]. 
The fourth component activities, namely the implementation of the environmentally-based curriculum. Integration is done by teachers by introducing environmentally-friendly automotive technologies that exist as a source of learning. Curriculum integration performed on all subjects that can be inserted through the EE charge syllabus and lesson plan, either on a compulsory, vocational, or local content subjects. Teachers are also required to consider the time and teaching methods to ensure the load can be taught EE properly [30].

One example of the integration of EE subjects namely light vehicle engine maintenance. In these subjects, there is a matter of regular maintenance engine emission control systems/bike light vehicles. Thereby exhaust gas emissions reduction technology such as catalytic converters can be used as a learning resource. Students are taught to control exhaust gas emissions through the application of the catalytic converter technology. Students are also trained to measure exhaust gas emissions on the vehicle by using exhaust gas analyzer and comparing the results of testing to the standards/criteria allowed by the government.

Fifth, the expected results of the curriculum development integrated with $\mathrm{EE}$ for automotive engineering study program at vocational high schools are produced graduates who have the skills and behavior competencies care for the environment. By the concept of sustainable development, it reflects that the orientation of the content, purpose and exact results will lead to the achievement of educational goals by the idea of SDGs [31].

\section{CONCLUSION}

Based on the results of the study and description of the exposure of the discussion above, then it can be concluded that the model of curriculum development integrated with EE at vocational high school is an ideal model when implemented in the adiwiyata program, especially for automotive engineering study program. The model has a solid foundation because it was developed through several steps that must be performed in sequence starting from the first step to the last step.

Curriculum studies consists of three indicators concluded that: (1) the legal basis used in developing the adiwiyata program should refer to Law Number 32 of 2009 on Environmental Protection and Management and Minister of Environment Regulation Number 05 of 2013 on Guidelines for Adiwiyata Program; (2) the concept of a green school developed was adopted from U.S. Green Building CouncilLeadership Energy and Environment Design (USGBC-LEED), Collaborative for High Performance Schools (CHPS), and U.S. Environmental Protection Agency (U.S. EPA); and (3) teaching materials used by teachers should contain potential and global environmental issues both global, national, and local, supported by much relevant literature and research.

SWOT analysis of four categories concluded that the development of a new curriculum model produces strategies that are capable of supporting and addressing the results of the SWOT analysis. Some of them, namely to support the poweropportunity (SO), the procedures used are (1) socialization of the EE for all the citizens of the school and surrounding communities; and (2) utilizing the available environmentally- friendly technologies. Overcoming strengths-threats (ST), the strategies used are (1) empower teachers to guide students completing their studies; (2) maximizing existing and creative infrastructure and facilities for the learning process of EE to be maximal; and (3) encourage the commitment of all of the school community to develop a green school.

Overcoming the weaknesses-opportunities (WO), the strategies used are (1) to provide training in the integration of EE to teachers; (2) analyzing the needs of infrastructure and facilities in accordance with the green schools used as reference criteria; and (3) rearrange the minimum $20 \%$ allocation of school budget for EE based on the results of school environmental assessment (SEA). Overcoming the weaknesses-threats (WT), the strategies used are (1) requires teachers to integrate subjects that are taught with the content of EE; (2) deepen understanding of the preparation of the $20 \%$ school budget to support adiwiyata program; and (3) explore information continuously about environmentally-friendly automotive technologies based on the environmental issues.

The action plan, based on four priority-scale considerations, concludes that there are four environmental issues that schools must complete by developing infrastructure and facilities. These environmental issues are (1) exhaust gas emission control technology; (2) opacity (smoke emission) control technology; (3) noise level control technology; and (4) waste management technology. After supporting infrastructure and facilities are available, program performance can be measured based on the instruments provided.

The curriculum development of an automotive engineering study program consists of four components of the adiwiyata program concludes that: first, curriculum development should begin with a school environmental assessment (SEA) and environmental protection and management budgeting is minimum $20 \%$ of the school's budget. Second, schools are required to make infrastructure and facilities in the form of environmental protection and management supporting technology in accordance with the needs of automotive engineering study programs, such as (1) catalytic converter technology to reduce $\mathrm{CO}, \mathrm{HC}$, and NOx emissions; (2) diesel particulate filter (DPF) technology to reduce $\mathrm{PM}_{10}$ emissions; (3) off-set tube type muffler technology to minimize noise level; dan (4) oil filter cleaner to reduce oil waste at school.

Third, in the manufacture of these technologies students are also required to participate actively. Thus, students can gain knowledge about environmentally-friendly automotive technology especially in the field of automotive engineering study program, can create, and know the impact of these technologies on the environment. Fourth, after the environmentally-friendly automotive technology available, teachers are required to integrate these technologies as a learning source through the syllabus and lesson plan, either on a compulsory, vocational, or local content subjects.

\section{REFERENCES}

[1] G. Brundtland, "Report of the World Commision on Environment and Development: Our Common Future," 1987.

[2] UNESCO, "The International Environmental Education Programme (IEEP)," Belgrade, 1975. 
[3] UNESCO, "Final Report: Intergovernmental Conference on Environmental Education. Organized by UNESCO in Cooperation with UNEP. Tbilisi, USSR. 14-26 October 1977,” Paris, 1978.

[4] The Constitution of the Republic of Indonesia of 1945, vol. 12, no. 16. 2013, pp. 81-87.

[5] Y. Anggraini Barus, Restu, and Darwin, "Analysis of Internalization Principles of Adiwiyata Mandiri Program in the Learning Process in Junior High School (Case Study at State Junior High School 3 Deli Serdang District),” Int. J. Sci. Basic Appl. Res., vol. 35, no. 1, pp. 241$251,2017$.

[6] Law No. 32 of 2009 on the Protection and Environmental Management (2009). Jakarta, Indonesia, 2009, pp. 1-110.

[7] Minister of Environment Regulation No. 05 of 2013 on Guidelines for Adiwiyata Program. Indonesia, 2013.

[8] I. Haris, "Promoting the Greening Curriculum: A note on the Implementation of Environmental Education in Indonesian School," Int. J. Appl. Environ. Sci., vol. 11, no. 1, pp. 309-323, 2016.

[9] A. S. Nugraheni, "Controversy a Policy Change in the Curriculum in Indonesia in Terms of the Point of View of Indonesian Language Subject," J. Educ. Pract., vol. 6, no. 2, pp. 53-62, 2015.

[10] C. J. Marsh, Key Concepts for Understanding Curriculum, Fourth. New York: Taylor \& Francis, 2009.

[11] C. R. Finch and J. R. Crunkilton, Curriculum Development in Vocational and Training Education, Fifth Edit. London: Allyn and Bacon, Inc, 1979.

[12] A Taisce, Green-Schools Programme. Dublin: Green-Schools Office, 2016.

[13] Minister of Environment, Guidelines for Adiwiyata: School which Care and Environment Cultured. Jakarta: Ministry of Environment and the Ministry of National Education of the Republic of Indonesia, 2011.

[14] US Green Building Council (USGBC), “About USGBC," 2018. [Online]. Available: https://new.usgbc.org/about. [Accessed: 18-Mar2018].

[15] M. Trowbridge, K. Worden, and C. Pyke, "Applying Green Building Principles of Market Transformation to Promote Healthy Places." National Academy of Medicine, Washington, D.C, p. 8, 2015.

[16] Center for Green Schools USGBC, "About Center for Green Schools," 2018. [Online]. Available: http://www.centerforgreenschools.org/about. [Accessed: 18-Mar-2018].

[17] N. H. Ramli, M. H. Masri, M. Zafrullah, H. M. Taib, and N. A. Hamid, "A Comparative Study of Green School Guidelines," Procedia - Soc. Behav. Sci., vol. 50, no. July, pp. 462-471, 2012.
[18] H. Bucaneg and C. E. Commission, "Collaborative for High Performance Schools ( CHPS ): The Process of Mainstreaming Efficiency in Action and the Evolution of CHPS History of the Collaborative for High Performance Schools Collaborative For High Performance Schools Organization Collaborativ," in ACEEE Summer Study on Energy Efficiency in Buildings, 2008, pp. 13-24.

[19] D. E. Gordon, "Green Schools as High Performance Learning Facilities," National Clearinghouse for Educational Facilities, Washington, D.C, 2010.

[20] CHPS, "Who We Are |," 2018. [Online]. Available: https://chps.net/who-we-are. [Accessed: 15-Apr-2018].

[21] NY-CHPS, NY-CHPS High Performance Schools Guidelines. Albany: New York State Education Department, 2007.

[22] X. Liu, "The U.S. Environmental Protection Agency A Historical Perspective on Its Role in Environmental Protection," Ludwig Maximilians University, 2010.

[23] EPA, Indoor Air Quality Tools for Schools. Reference Guide. Washington, DC: U.S. Environmental Protection Agency (EPA), 2009.

[24] Warju, S. Prawiro, Soenarto, and M. D. Hartmann, "Evaluating the Implementation of Green School (Adiwiyata) Program : Evidence from Indonesia," Int. J. Environ. Sci. Educ., vol. 12, no. 6, pp. 1483-1501, 2017.

[25] C. E. Notar and V. Cole, "Literature Review Organizer," Int. J. Educ., vol. 2, no. 2, pp. 1-17, 2010 .

[26] Sugiyono, Quantitative Research Methods, Qualitative and R\&D. Bandung: Alfabeta, 2006.

[27] K. Gleissner, Greening TVET for Sustainable Development. Bonn: UNESCO-UNEVOC International Centre for Technical and Vocational Education and Training, 2013.

[28] USGBC, Green Building Design, and Construction with Global Alternative Compliance Paths. Washington, DC: U.S. Green Building Council (USGBC), 2009.

[29] A. A. Thompson, M. A. Peteraf, J. E. Gamble, and A. J. S. III, Crafting and Executing Strategy Concepts and Cases, Twentieth. USA: McGrawHill, 2016.

[30] A. Kitiashvili and T. Abashidze, "Integrating Environmental Education in Vocational Education and Training ( VET ): The case of Georgia," in Third International Conference on Advances in Social Science, Management, and Human Behaviour - SMHB 2015, 2015, pp. 10-12.

[31] UNESCO, Greening Technical and Vocational Education, and Training. Germany: United Nations Educational, Scientific and Cultural Organization 7 and UNESCO-UNEVOC International Centre for TVET UN Campus, 2017. 